\title{
Infiltration tests at the landsliding of the right bank of the "Juan de Grijalva" River, Chiapas, Mexico
}

\author{
J. D. Martínez-Nájera, C. Sánchez-Linares, V. Mata-Villavicencio, \\ S. González-Ramírez, F. Gama-Martínez \& I. Moreno-Valle \\ Comisión Federal de Electricidad, Mexico
}

\begin{abstract}
Infiltration of water and of leached substances through the capillary zone depends on the physical and structural characteristics of the ground and subsoil as well as on the intensity and duration of the rainfall or irrigation, vegetal cover, terrain slope, drainage pattern, etc. Infiltration models can be classified in three categories: semi-empirical, of Green-Ampt and of Richards' type. The results of infiltration models become the input of other flow and transport models, and of hydrologic balances in basins. Field works were carried out to quantify the rates of infiltration by means of Porchet's tests, and analyzed in the context of the semi-empirical method of Horton, in the sliding zone of the right bank of Juan de Grijalva River, between the hydroelectric dams of Malpaso and Peñitas, Chiapas, Mexico. The results indicate that the area known as Zona de Relictos maintains the highest average values of infiltration, and it is followed by units $U$ $I, U-I I$ and $U$-III. Realized tests fall within the scope of the hydrologic studies and engineering works that Comisión Federal de Electricidad is performing in the site to guarantee the stability of the sliding zone, by draining the groundwater flow and channeling the runoff after rainfall events.
\end{abstract}

Keywords: infiltration tests and models, rainfall, runoff.

\section{Introduction}

The knowledge and quantification of the flow of water through the capillary zone is necessary to solve problems related with the prediction of infiltration and runoff, sediment transport, flood control, protection of slopes and rivers banks as 
is the case, aquifer deep recharge, availability of water for biota, evaluation and progression of pollution, etc. Physical and structural characteristics of the soil determine the flow pattern of water in any particular region. Results derived from infiltration models become the input data for models describing flow of water and transport of contaminants through vadose and saturated zones as well as of models establishing hydrologic balances in watersheds. In this respect, infiltration models are developed to integrate atmospheric hydrology with surface and underground hydrology.

The purpose of the project is to quantify infiltration rates with Horton's method [1, 2], implemented by means of Porchet-type field tests executed at the right bank of Juan de Grijalva river in a landsliding zone. Tests were performed in the units called Cuerpo Principal, Zona de Relictos and Zona de Amortiguamiento that constitute the slide area of the event occurred in November 4, 2007 in which the slope of the hill slid and totally obstructed the passage of the water of Grijalva river, near the namesake town located between Malpaso and Peñitas hydroelectric dams, figure 1. The engineering scope of tests is part of the hydrological studies executed by Comisión Federal de Electricidad for guaranteeing the slope stability of the sliding zone by draining the groundwater flow and channeling the surface runoff after rainfall events in the site. It is therefore necessary to characterize the hydrology and develop the corresponding models to estimate water balances and to evaluate catchment areas of works of pick up and lightening of the excess of water in the zone.

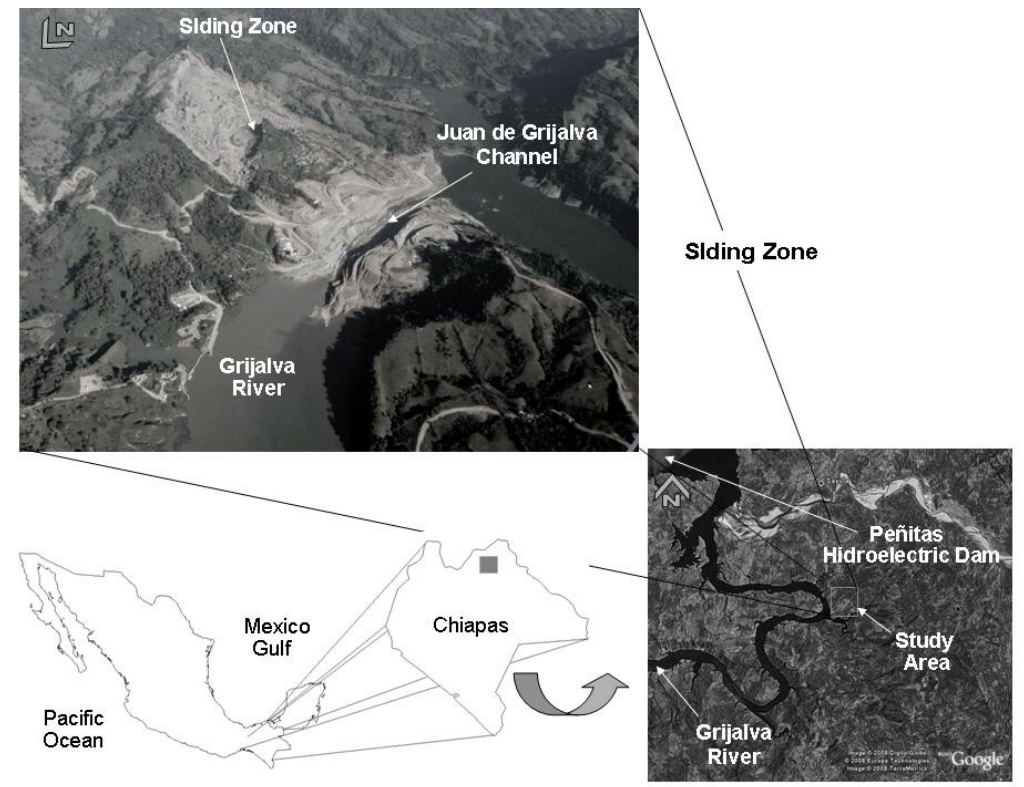

Figure 1: Location of the site. 


\section{Context of infiltration models}

Soil infiltration models provide an analytical framework for understanding the mechanisms and hydrologic controls of the vadose zone. For managers of water resources, infiltrations models may provide an essential support for planning and screening of alternative policies, regulations and engineering designs. For aquifer mathematical modelers provides the recharge terms of water and source terms of substances that migrates from the surface to subsurface flow. Practical infiltration models can be classified into three categories: semi-empirical, of Green-Ampt, and of Richards type.

In semi-empirical models function types are settled down, whose form fits with measured values in field, and then proceed to the physical interpretation of the observed process. Type functions provide infiltration rates but lack of information about the distribution of water content in the soil, and their relationship with the unsaturated potential and hydraulic conductivity. As examples of this type of models reference can be made to those developed in $[1-4]$.

Green and Ampt [5] deducted infiltration relationships based on physical principles under the concept of advance of a piston-type wet front. Among infiltration models based on the approach of Green-Ampt mention can be made of those developed in [6-8], these models takes into account the potential, moisture content and conductivity in the capillary zone.

Models based on the equations of Richards are founded on the analytical or numerical solution of mass balance at the non-saturated zone in combination with the law of Darcy-Buckingham. Developed models to solve particular cases of Richards' equation are given in [9-11]. The most important formulations of Richards' equation are those based in the moisture content $(\theta)$ and on the nonsaturated potential $(h)$.

In the present work Horton [1, 2] semi-empirical procedure was used and implemented in field by means of Porchet's tests [12-15] due to the possibility of obtaining practical results through the use of simple, direct, quick, easily implemented and low-cost field techniques, figures 2 and 3.

Ravi and Williams [12] analyze techniques to estimate field infiltration and conclude that semi-empirical techniques are practical and widely used. Williams et al. [13] propose different field-oriented methods to quantify semi-empirical procedures, including those of the Horton's type. Montecinos et al. [16] analyze various semi-empirical methods based on the solution to Richards' equation to calculate hydraulic conductivity in silty sands and indicate that Porchet's tests show the most uniform behavior as a function of the percentage of fine soil and degree of relative density. Nave et al. [17] characterize infiltration process at piedmont by using techniques of Horton, Green-Ampt and solutions of the equation of Richards of Philip [9] and Smith [18] types. Jutla [19] evaluates different infiltration models from an integrated approach of basin modeling and from the perspective of dynamic systems. Samper et al. [20] resort to the procedure of Horton to estimate infiltration in a basin model. Zhenxue and Samper [21] present a methodology to estimate unsaturated flow parameters 
based on minimizing a functional to allow the calculation of parameters of the retention curve and of the relative permeability in laboratory bentonite columns.

\section{Infiltration model of Horton}

Different factors are involved in the infiltration and percolation phenomena, among which special mention should be made of the physical characteristics and soil structure, subsoil properties, topsoil and vegetation, moisture content and soil temperature as well as intensity and duration of rainfall or irrigation events, ground gradient and drainage pattern. Infiltration capacity of the soil decreases with recharging time starting at a peak value when rains begin, and tending to a stable value in the course of time. Horton $[1,2]$ relates it with the duration of rainfall with intensity exceeding the infiltration rate at any time, by means of the following expression:

$$
f(t)=f_{c}+\left(f_{0}-f_{c}\right) e^{-B t},
$$

where: $f$ is the infiltration capacity as function of time $[\mathrm{L} / \mathrm{T}] ; f_{0}$ the maximum infiltration capacity at the beginning of the event $[\mathrm{L} / \mathrm{T}] ; f_{c}$ the long-term asymptotic infiltration capacity $[\mathrm{L} / \mathrm{T}] ; B$ is a positive decline constant depending on the soil $\left[\mathrm{T}^{-1}\right]$; and $t$ the time elapsed since the beginning of rain or irrigation [T].

Determination of coefficients $f_{0}, f_{c}$ and $B$ is made experimentally in the field; generally the relation $f_{0} \geq f_{c}$ is satisfied. Qualitative characteristics of eqn (1) indicates that the function decreases exponentially so that when $t=0$ then $f(0)=f_{0}$, whereas when $t \rightarrow \infty, \quad e^{-B t} \rightarrow 0$ and $f(t \rightarrow \infty)=f_{c}$. The infiltration volume is the product of the catchment area by the integral of the infiltration capacity eqn (1) in the duration of the event.

The Horton's model is implemented in field by means of approaches of type proposed by Porchet $[14,15]$. In Porchet's tests a cylindrical hole with radius $r$ is excavated in the ground and it is filled with water until reaching a height $h$, figure 2, so that the surface $S$ through which water is infiltrated becomes $S=\pi r(2 h+r)$. Mass balance indicates that infiltrated volume in the time interval $d t$ is equal to the infiltration capacity times the infiltration area, i.e. $-\pi r^{2}(d h / d t)=\pi r(2 h+r) f$. Then separating variables it is found that $f d t=-r(d h /(2 h+r))$; integrating this latter equation assuming that the variation of $f$ is small within the time interval $t_{2}-t_{1}$, the following expression is obtained $f=r\left(\operatorname{In}\left(2 h_{1}+r\right)-\operatorname{In}\left(2 h_{2}+r\right)\right) / 2\left(t_{2}-t_{1}\right)$. Then, to determine the infiltration rate $f$ it is necessary to measure in field the time series $\left(t_{i}, h_{i}\right)_{i=1}^{N}$, where $N$ is the total number of readings. 


\section{Site location and local geologic model}

The area under study is located between Malpaso and Peñitas hydroelectric dams, at the right bank of the Grijalva river, at geographic coordinates $17^{\circ} 21^{\prime} 51^{\prime \prime}$ North and $93^{\circ} 23^{\prime} 00^{\prime \prime}$ West at a distance of $12 \mathrm{~km}$ from Peñitas dam in the territory where the Malpaso syncline is found at the west and La Unión anticline to the east; the site is referred to as the physiographic provinces of Montañas del Norte and the Planicie Costera del Golfo, figure 1. The site belongs to the hydrological basin of the Grijalva River and it has a rainy climate with rain falling throughout the year. Drainage is of dendritic type and varies from parallel to rectangular associated to the geologic structures. The most relevant morphologic features correspond to narrow meander forms of the Grijalva River associated to the lithologic features of the site as well as to the geometry of fractures and faults affecting the rock mass particularly in the northeast direction. The sliding hillside is locally known as Cerro de la Pera and it is located at the narrowest meander, $900 \mathrm{~m}$ in width, downstream from the Malpaso dam and upstream of Peñitas dam.
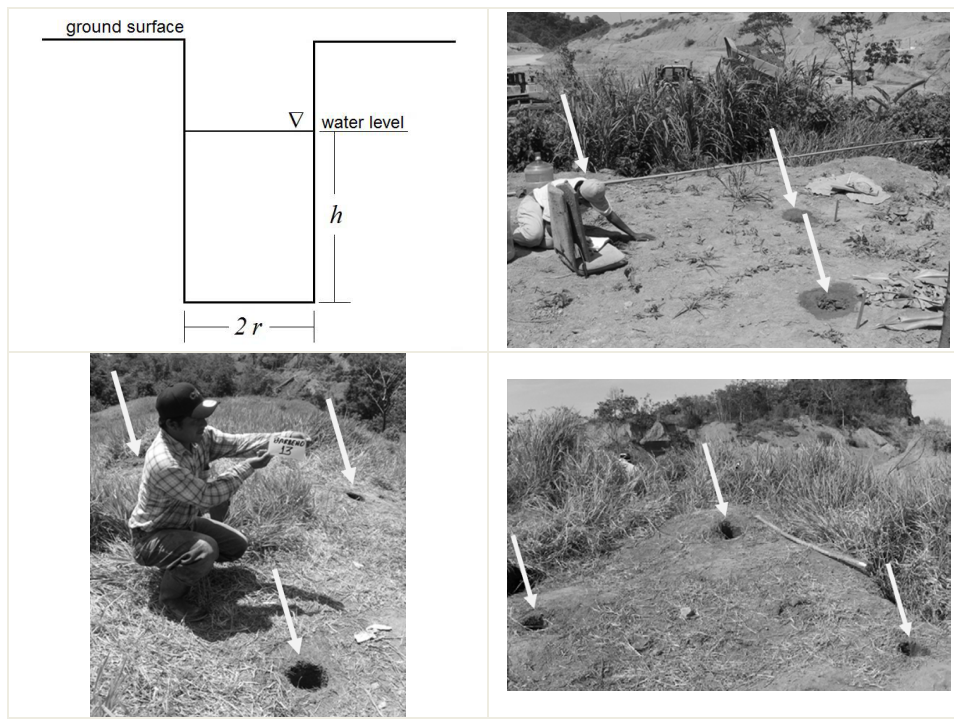

Figure 2: Infiltration schema of Porchet, photographic details of tests.

The site is constituted by alternated layers of fine-grained sandstone, siltstones, and dark grey clay shale found in thin to laminated strata; the sequence is covered by grayish brown ochre silty sandstones in thin to intermediate strata as well as by a thick layer of reddish to brown residual soil. At some outcropping found at the Juan de Grijalva town the base can be observed as constituted by conglomerate-type sandstone and by polymicthic conglomerates constituted by fragments of sub-rounded igneous rocks packed in 
a sandy matrix. The sliding zone is bounded at the north and at the south by lateral displacement faults that are mutually parallel and show a Northeast $60^{\circ}$ Southwest strike; toward the northeast, the block has been segmented by La Laja fault that is a regional fault of normal type, figure 1. Following the event of November 4, 2007 the hillside became fragmented in units $U-I, U-I I, U-I I I$ and the so-called Zona de Relictos, whereas the external area known as Zona de Amortiguamiento which remained undisturbed. Units $U-I, U-I I$ and $U-I I I$ are also known as Cuerpo Principal, figure 3.

\section{Work program and field results}

Porchet tests were performed in 43 sites, at each site three shallow borings were drilled with $6 "$ in diameter, depth of $30 \mathrm{~cm}$ and initial hydraulic head of $30 \mathrm{~cm}$. In the bores were performed three variable-head starting series with duration of 30 minutes each, one test with constant head until the infiltrated volume per unit of time became constant and three series of variable head until depleting the initial hydraulic head, figure 3 depicts tests locations.

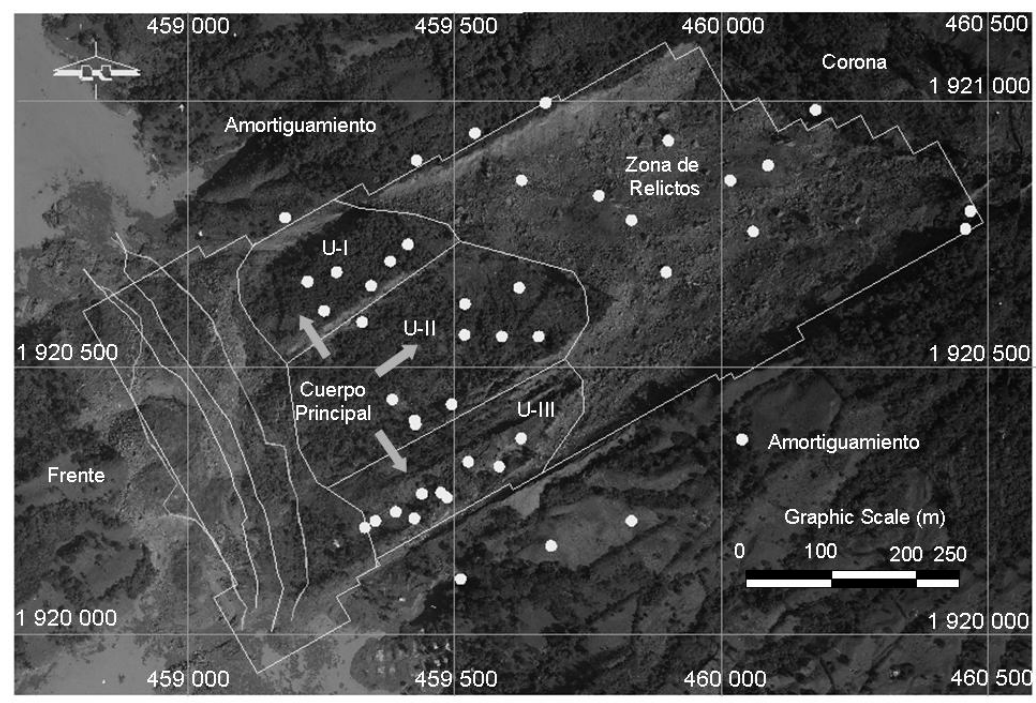

Figure 3: Location of Porchet's test sites.

Starting test series are focused on determining the value of $f_{0}$ of eqn (1). Table 1 shows average, maximum and minimum values obtained. After analyzing the results obtained for units $U-I, U-I I, U-I I I$ and for Zona de Relictos it can be determined that Zona de Relictos maintains the largest global average of infiltration rate equal to $13,44 \mathrm{~cm} / \mathrm{min}$, followed by unit $U-I I I$ with $5,65 \mathrm{~cm} / \mathrm{min}$, then by unit $U-I$ with $5,57 \mathrm{~cm} / \mathrm{min}$, and finally by unit $U-I I$ with $5,29 \mathrm{~cm} / \mathrm{min}$. It should be observed that there are no major differences among units themselves; 
Table 1: $\quad$ Average, maximum and minimum values of $f_{0}$.

\begin{tabular}{|c|c|c|c|}
\cline { 2 - 4 } \multicolumn{1}{c|}{} & $\begin{array}{c}\text { Average values of starting } \\
\text { infiltration rate }\end{array}$ & $\begin{array}{c}\text { Maximum values of } \\
\text { starting infiltration rate }\end{array}$ & $\begin{array}{c}\text { Minimum values of } \\
\text { starting infiltration rate }\end{array}$ \\
\hline Unit & $f_{0}(\mathrm{~cm} / \mathrm{min})$ & $f_{0}(\mathrm{~cm} / \mathrm{min})$ & $f_{0}(\mathrm{~cm} / \mathrm{min})$ \\
\hline$U-I$ & 5,57 & 11,63 & 0,35 \\
\hline$U-I I$ & 5,29 & 13,09 & 0,78 \\
\hline$U-I I I$ & 5,65 & 17,62 & 0,52 \\
\hline Zona de Relictos & 13,44 & 24,00 & 3,23 \\
\hline
\end{tabular}

on the other hand, Zona de Relictos maintains a rate of about twice the value identified for the units.

The test series under constant head makes it possible to estimate the value of $f_{c}$ of eqn (1). Table 2 shows average, maximum and minimum values for each unit. It can be determined that Zona de Relictos maintains the largest global average of the infiltration rate with a value of $1,13 \mathrm{~cm} / \mathrm{min}$ followed by unit $U-I$ with $0,83 \mathrm{~cm} / \mathrm{min}$, then by unit $U-I I I$ with $0,43 \mathrm{~cm} / \mathrm{min}$, and finally by unit $U-I I$ with $0,39 \mathrm{~cm} / \mathrm{min}$. Approximate average values can be found among the different units with small differences. The Zona de Relictos maintains a rate of about twice the value corresponding to the average of the units. A relevant aspect that is worth mentioning refers to the average time to reach the constant infiltration rate, it was found to be of approximately 60 minutes in the series of test performed.

Finally, variable head tests until depleting the initial hydraulic head were made, in addition to parameter $B$ with this type of tests it is possible to determine the average infiltration rates to estimate recharge factors in the zone under study. Table 3 presents the average, maximum and minimum infiltration rates for each zone. The Zona de Relictos maintains the largest global average of infiltration rate with a value of $19,51 \mathrm{~cm} / \mathrm{min}$; even in the case of eliminating the bias of $355,68 \mathrm{~cm} / \mathrm{min}$ there would remain an average of $6,06 \mathrm{~cm} / \mathrm{min}$. It is followed by unit $U-I$ with $1,23 \mathrm{~cm} / \mathrm{min}$, then by unit $U-I I$ with $0,99 \mathrm{~cm} / \mathrm{min}$, and finally by unit $U-I I I$ with $0,77 \mathrm{~cm} / \mathrm{min}$. Once again, it can be observed that all

Table 2: $\quad$ Average, maximum and minimum values of $f_{c}$.

\begin{tabular}{|c|c|c|c|}
\cline { 2 - 4 } \multicolumn{1}{c|}{} & $\begin{array}{c}\text { Average values of } \\
\text { stationary infiltration rate }\end{array}$ & $\begin{array}{c}\text { Maximum values of } \\
\text { stationary infiltration rate }\end{array}$ & $\begin{array}{c}\text { Minimum values of } \\
\text { stationary infiltration rate }\end{array}$ \\
\hline Unit & $f_{c}(\mathrm{~cm} / \mathrm{min})$ & $f_{c}(\mathrm{~cm} / \mathrm{min})$ & $f_{c}(\mathrm{~cm} / \mathrm{min})$ \\
\hline$U-I$ & 0,83 & 1,50 & 0,33 \\
\hline$U-I I$ & 0,39 & 1,22 & 0,04 \\
\hline$U-I I I$ & 0,43 & 1,69 & 0,08 \\
\hline Zona de Relictos & 1,13 & 9,19 & 0,13 \\
\hline
\end{tabular}


Table 3: $\quad$ Average, maximum and minimum values of $f$.

\begin{tabular}{|c|c|c|c|}
\cline { 2 - 4 } \multicolumn{1}{c|}{} & $\begin{array}{c}\text { Average value of infiltration } \\
\text { rate until depleting the initial } \\
\text { head }\end{array}$ & $\begin{array}{c}\text { Maximum value of } \\
\text { infiltration rate until } \\
\text { depleting the initial head }\end{array}$ & $\begin{array}{c}\text { Minimum value of } \\
\text { infiltration rate until } \\
\text { depleting the initial } \\
\text { head }\end{array}$ \\
\hline Unit & $f(\mathrm{~cm} / \mathrm{min})$ & $f(\mathrm{~cm} / \mathrm{min})$ & $f(\mathrm{~cm} / \mathrm{min})$ \\
\hline$U-I$ & 1,23 & 6,15 & 0,15 \\
\hline U-II & 0,99 & 4,12 & 0,06 \\
\hline U-III & 0,77 & 2,24 & 0,03 \\
\hline Zona de Relictos & 19,51 & 355,68 & 0,09 \\
\hline
\end{tabular}

units maintain approximate average values and therefore differences among them are minimal. The Zona de Relictos keeps a rate of about 20 times the average value presented in all units.

\section{Conclusions}

The quantification of the flow of water through the capillary zone is necessary to solve problems related with the prediction of infiltration and runoff, sediment transport, flood control, protection of slopes and river banks as is the case, evaporation-transpiration, aquifer recharge, availability of water for biota, evaluation of pollution, etc. Among the various possibilities for estimating infiltration rates in the field, it was decided to use the infiltration model proposed by Horton because it is possible to be easily implemented in field. Porchet's tests are implemented at the hillside sliding zone located in the right bank of Juan de Grijalva river in the State of Chiapas, Mexico, in the zones known as Cuerpo Principal, Zona de Relictos and Zona de Amortiguamiento that constitute the sliding material areas after the event of November 4, 2007.

In all analyzed cases the Zona de Relictos maintains the largest average values of infiltration rates, depending on the type of tests it is followed by the units constituting the Cuerpo Principal area. In the case of starting series the average infiltration rate at Zona de Relictos amounts to $13,44 \mathrm{~cm} / \mathrm{min}$, $5,65 \mathrm{~cm} / \mathrm{min}$ at unit $U-I I I, 5,57 \mathrm{~cm} / \mathrm{min}$ at unit $U-I$, and to $5,29 \mathrm{~cm} / \mathrm{min}$ at unit $U$ II. In constant head tests Zona de Relictos maintains an infiltration rate of $1,13 \mathrm{~cm} / \mathrm{min}$, unit $U-I$ of $0,83 \mathrm{~cm} / \mathrm{min}$, unit $U-I I I$ of $0,43 \mathrm{~cm} / \mathrm{min}$, and unit $U-I I$ of $0,39 \mathrm{~cm} / \mathrm{min}$. In the series of variable head until depleting the initial head, the Zona de Relictos evidences an infiltration rate of $19,51 \mathrm{~cm} / \mathrm{min}$, followed by unit $U-I$ with $1,23 \mathrm{~cm} / \mathrm{min}$, then by unit $U-I I$ with $0,99 \mathrm{~cm} / \mathrm{min}$, and finally by unit $U$ III with $0,77 \mathrm{~cm} / \mathrm{min}$. Lastly, time required to reach constant infiltration becomes approximately equal to 60 minutes. 


\section{Acknowledgements}

Thanks are expressed to Ing. Gustavo Arvizu Lara, Ing. Moisés Dávila Serrano, Ing. Juan de Dios Alemán Velásquez and Ing. Alfredo Jiménez Trigos for their valuable opinions in the course of this project.

\section{References}

[1] Horton, R.E. The role of infiltration in the hydrological cycle. Trans. American Geophys. Union, Vol. 14, pp. 446-460, 1933.

[2] Horton, R.E. An approach towards a physical interpretation of infiltration capacity. Soil Science of America Proceedings, Vol. 5, pp. 399-417, 1940.

[3] Kostiakov, A.N. On the dynamics of the coefficient of water percolation in soils and on the necessity of studying it from a dynamic point of view for the purposes of amelioration. Trans. Com. Int. Soc. Soil Sci. 6th Moscow, pp. 17-21, 1932.

[4] USDA - Natural Resources Conservation Service. Part 630 Hydrology. Chapter 10. Estimation of direct runoff from storm rainfall. National Engineering Handbook, 79 pp, 2004.

[5] Green, W.H. and Ampt, C.A. Studies on soil physics, I. The flow of air and water through soils. Journal of Agricultural Science IV, pp. 1-24, 1911.

[6] Bouwer, H. Infiltration of water into nonuniform soil. Journal of Irrigation and Drainage, Division of ASCE, Vol. 95, No. IR4, pp. 451-462, 1969.

[7] Morel-Seytoux, H.J. and Khanji, J. Derivation of an equation of infiltration. Water Resources Research, Vol. 10, No. 4, pp. 795-800, 1974.

[8] Smith, R.E. and Parlange, J.Y. A parameter-efficient hydrologic infiltration model. Water Resources Research, Vol. 14, No. 3, pp. 525538, 1978.

[9] Philip, J.R. Theory of infiltration. Advances in Hydroscience, Vol. 5 , pp. 215-296, 1969.

[10] Raats, P.A.C. Steady infiltration from sources at arbitrary depth. Soil Science Society of America Proceedings, Vol. 36, pp. 399-401, 1972.

[11] Eagleson, P.S. Climate, soil and vegetation, 3. A simplified model of soil moisture movement in the liquid phase. Water Resources Research, Vol. 14, No. 5, pp. 722-730, 1978.

[12] Ravi, V. and Williams, J.R. Estimation of infiltration rate in vadose zone: compilation of simple mathematical models. Volume I. EPA/600/R97/128a, 84 pp, 1998.

[13] Williams, J.R., Ouyang, Y. and Chen, J.S. Estimation of infiltration rate in vadose zone: Application of selected mathematical models. Volume II. EPA/600/R-97/128b, 117 pp, 1998.

[14] Custodio, E. and Llamas, M.R. Hidrología subterránea, Tomo I. Segunda edición, Ed. Omega, Barcelona, 550 pp, 1983.

[15] Bedient, P.B. and Huber, W.C. Hydrology and floodplain analysis. Addison-Wesley, $250 \mathrm{pp}, 1985$. 
[16] Montecinos, A.J., Montalva, G.A. and Vargas, J. Comparación y proposición de métodos para determinar la conductividad hidráulica en arenas limosas. Ingeniería Hidráulica en México, Vol. XXIII, No.2, II Época, pp. 147-152, 2008.

[17] Nave, Marcela, Pedrani, A., Vich, A.I.J. and Mariani, A. Caracterización del proceso de infiltración en el piedemonte Mendocino. Manejo Ecológico de Cuencas, IANIGLA 1973-2002, pp. 145-149, 2002.

[18] Smith, R.E. Approximate soil water movement by kinematic characteristics. Soil Science Society of America Journal, Vol. 47, pp. 3-8, 1983.

[19] Jutla, A.S. Hydrologic modeling of reconstructed watersheds using system dynamics approach. MsC Thesis, Department of Civil and Geological Engineering, University of Saskatchewan, Canada, 187 pp, 2006.

[20] Samper, J., Huguet, Ll., Ares, J. and García-Vera, M.A. Modelos interactivos de balance hidrológico. Estudios de la Zona no Saturada del Suelo, ICIA, Tenerife, pp. 187-193, 1999.

[21] Zhenxue, D. and Samper, J. Estimación automática de parámetros de flujo no saturado mediante ensayos de infiltración. Estudios de la Zona no Saturada del Suelo, Eds. R. Muñoz-Carpena, A. Ritter, C. Tascón, ICIA: Tenerife, pp. 175-180, 1999. 